\title{
Bakteriuria Asimtomatik pada Anak Sekolah Dasar Laki-laki dan Perempuan Usia 9-12 tahun
}

\author{
Sondang M. Lumbanbatu, Rusdidjas, Rafita Ramayati, Ramona Tobing
}

\begin{abstract}
Bakteriuria asimtomatik adalah bakteriuria bermakna pada anak yang kelihatan sehat tanpa gejala klinis infeksi ginjal dan saluran kemih. Tujuan penelitian ini untuk melihat perbedaan dan prevalensi bakteriuria asimtomatik pada anak sekolah dasar usia 9-12 tahun menurut jenis kelamin. Telah dilakukan penelitian secara studi cross sectional deskriptif terhadap urin murid sekolah dasar laki-laki dan perempuan usia 9-12 tahun di Kecamatan Medan, Tuntungan, Medan yang dipilih secara acak pada bulan Januari sampai Maret 2001. Kriteria eksklusi apabila dijumpai anak dengan gejala infeksi saluran kemih, enuresis nokturnal atau diurnal, sedang menderita kelainan anatomi dan fungsional saluran urogenital yang dapat dideteksi secara klinis. Sampel yang diambil adalah urin pagi pancar tengah dan dibiakkan di Laboratorium Mikrobiologi FK-USU Medan. Bakteruria bermakna bila ditemukan $\geq 100.000$ koloni bakteria per $\mathrm{ml}$ urin. Dari 200 anak (137 perempuan, 63 laki-laki) dijumpai 16 bakteriuria bermakna terdiri dari $14(7 \%)$ perempuan dan $2(1 \%)$ laki-laki, berbeda bermakna $(p<0,05)$. Jenis bakteriuria E. coli 6, Staphylococcus epidemidis 6, Staphylococcus aureus 2, Klebsiella 1, dan Pseudomonas 1 . Kesimpulan, adanya perbedaan bermakna bakteriuria asimtomatik pada anak sekolah dasar laki-laki dan perempuan usia 9-12 tahun, dengan kuman penyebab terbanyak E. coli dan Staphylococcus epidermidis.
\end{abstract}

Kata kunci : bakteriuria asimtomatik, infeksi saluran kemih, urin pancar tengah

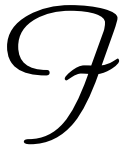

nfeksi saluran kemih (ISK) merupakan penyebab kedua morbiditas penyakit pada anak setelah infeksi saluran nafas. ${ }^{1-3}$ Pada anak ISK sering tidak terdiagnosis. Pada sebuah penelitian di Portsmouth dan South East Hampshire, Inggris, angka kejadian ISK 20 kali lebih banyak dari yang diyakini sebelumnya. ${ }^{4,5}$ ISK dapat dibagi atas simtomatik dan asimtomatik. Disebut simtomatik bila dijumpai bakteriuria bermakna disertai gejala klinis seperti sakit buang air kecil (BAK), sering BAK dan rasa ingin miksi terus menerus dengan atau tanpa demam dan nyeri pinggang. ${ }^{1-11,14}$

Alamat korespondensi:

Dr. Sondang M. Lumbanbatu, Sp.A.

Bagian Ilmu Kesehatan Anak, Fakultas Kedokteran Universitas Sumatera

Utara / RS. H. Adam Malik Jl. Bunga Lau no. 17 Medan.

Telepon: 061-8360405, 8360143, 836034 Fax: 061-8361721.
Bakteriuria asimtomatik dapat terjadi pada anak usia sekolah dan dapat menyebabkan parut ginjal sehingga perlu dipertimbangkan untuk melakukan penyaringan bakteriuria pada anak-anak sehat. ${ }^{1-6}$ Walaupun sebagian besar anak dengan ISK mempunyai prognosis yang baik, pada sebagian kecil dapat terjadi komplikasi, khususnya bila disertai kelainan obstruktif dan refluks vesiko-ureter. ${ }^{1,9,11}$ Diagnosis dini dan pengobatan yang tepat dan adekuat merupakan hal yang penting untuk mencegah infeksi menjadi kronik dan berlanjut menjadi pielonefritis kronik dengan kerusakan ginjal yang progresif menuju ke arah gagal ginjal kronik. ${ }^{1-6,9}$

Penelitian ini bertujuan untuk menentukan perbedaan dan prevalensi bakteriuria asimtomatik dan untuk melihat jenis bakteri penyebab bakteriuria asimtomatik pada anak sekolah dasar (SD) laki-laki dan perempuan usia 9-12 tahun. 


\section{Subjek dan Cara Kerja}

Penelitian dilakukan setelah mendapat persetujuan dari Komite Medik RSUP H. Adam Malik, Medan. Penelitian ini bersifat studi cross sectional terhadap anak SD yang sehat berusia 9-12 tahun di Kecamatan Medan Tuntungan, Medan. Populasi target adalah semua anak usia 9-12 tahun di beberapa SD di Kecamatan Medan Tuntungan, Medan. Penelitian dilakukan sejak bulan Januari sampai Maret 2001. Data dikumpulkan dengan mempergunakan kuesioner terancang yang berisi identitas anak, identitas orang tua, pertanyaan mengenai higiene dan sanitasi seperti sumber air mandi, cuci, kakus (MCK), apakah anak cebok dengan air bersih sesudah BAK, anak cebok dengan air bersih sesudah buang air besar (BAB), anak sering sulit $\mathrm{BAB}$, anak suka menahan air kencing dan apakah anak malas minum. Mengenai riwayat ISK ditanyakan apakah anak sudah disirkumsisi, pernah sakit $\mathrm{BAK}$, nyeri pinggang, merasa ingin BAK terus menerus, sering-sering BAK, kencing berdarah, kencing keruh, demam tinggi/menggigil, mengompol. Juga dilakukan pemeriksaan fisik dengan mengukur berat badan, tinggi, badan dan melihat ada tidaknya kelainan fisik dan kelainan anatomi genitalia luar yang dapat dideteksi secara klinis. Murid sekolah dimasukkan dalam penelitian bila orang tua peserta sudah memberikan pernyataan kesediaan secara tertulis. Penentuan besar sampel untuk lokasi penelitian dengan cara non probability sampling dengan metode judgement sampling, dilakukan dengan stratified random sampling. Kriteria inklusi semua anak usia 912 tahun di beberapa SD di Kecamatan Medan Tuntungan. Kriteria eksklusi anak dengan gejala ISK seperti demam, sakit BAK, sering BAK, rasa ingin BAK terus-menerus, sakit pinggang, menggigil, nyeri sudut costovertebral, enuresis nokturnal ataupun diurnal, sedang menderita ISPA, sedang mendapat menstruasi, sedang minum antibiotik, menderita kelainan anatomi dan fungsional saluran urogenital yang dapat dideteksi secara klinis. ${ }^{1,3}$

\section{Metoda Laboratorium}

Urin yang diperiksa adalah urin pagi yang telah terkumpul dalam kandung kemih minimal empat jam. Orifisium uretra eksterna dan daerah sekitarnya dibersihkan tiga kali dengan air sabun, disiram dan dikeringkan. Pada anak laki-laki preputium diretraksi dan pada anak perempuan labia mayor dikuakkan dan vestibulum vagina dicuci dengan sabun, kemudian diseka 3 atau 4 kali dengan kasa steril. ${ }^{1,3,11}$ Urin pancar tengah ditampung dalam botol steril bermulut lebar dan bertutup. Sampel urin dimasukkan dalam termos yang berisi es. Pemeriksaan hitung jumlah bakteri (HJB) dilakukan kurang dari 1 jam setelah penampungan atau kurang dari 24 jam jika disimpan pada suhu $4^{\circ} \mathrm{C}$. Dilakukan dengan menggunakan sengkelit bertara $0,001 \mathrm{ml}$ pada permukaan media agar darah dan agar MacConkey, dieramkan pada suhu $37^{\circ} \mathrm{C}$ selama $20-24$ jam dan dihitung jumlah koloni yang ada. ${ }^{1,3,13,14}$ Biakan dilakukan di laboratorium mikrobiologi FK-USU Medan. Bakteriuria bermakna bila ditemukan $\geq 100.000 \mathrm{koloni} / \mathrm{ml}$ urin. ${ }^{1-11,13-15}$

\section{Analisis statistik}

Prevalensi bateriuria asimtomatik pada anak laki-laki dan perempuan serta jenis bakteri penyebab bakteriuria asimtomatik dianalisis secara deskriptif. Untuk melihat perbedaan bakteriuria asimtomatik pada anak laki-laki dan perempuan digunakan uji proporsi, dianggap bermakna bila nilai $p<0,05 .^{12}$

\section{Hasil}

Dari 200 sampel dijumpai usia rerata 10,7 tahun, terdiri dari 137 (68,5\%) anak perempuan dan 63 $(31,5 \%)$ anak laki-laki. Umur terbanyak 11 tahun yaitu $72(36,0 \%)$ anak dan status gizi $(\mathrm{BB} / \mathrm{U})$ terbanyak adalah gizi sedang yaitu $107(53,5 \%)$ anak seperti ditunjukkan dalam Tabel 1.

Urin pancar tengah yang menunjukkan bakteriuria bermakna didapat pada $16(8 \%)$ orang, bakteriruria tidak bermakna pada 146 (73\%) anak dan tidak ada pertumbuhan bakteri sebanyak 38 orang (19\%). Dijumpai perbedaan jumlah bakteriuria asimtomatik antara laki-laki (2 anak) dan perempuan (14 anak) dengan nilai $\mathrm{p}<0,05$, seperti ditunjukan dalam Tabel 2 .

Bakteriuria asimtomatik paling banyak dijumpai pada usia 11 tahun yaitu $7(43,7 \%)$ anak dan berdasarkan status gizi dijumpai 4 anak $(25,0 \%)$ anak dengan gizi baik, $11(68,8 \%)$ anak gizi sedang dan 1 $(6,2 \%)$ anak dengan gizi kurang (Tabel 3).

Dari data higiene dan sanitasi dijumpai 13 anak 
Tabel 1. Karakteristik sampel

\begin{tabular}{lll}
\hline Karakteristik & $\mathrm{n}$ & $\%$ \\
\hline Jenis Kelamin & & \\
Laki-laki & 63 & 31,5 \\
Perempuan & 137 & 68,5 \\
Usia (tahun) & & \\
9 & 32 & 16,0 \\
10 & 50 & 25,0 \\
11 & 72 & 36,0 \\
12 & 46 & 23,0 \\
Status Gizi (BB/U) & & \\
Baik & 76 & 38,0 \\
Sedang & 107 & 53,5 \\
Kurang & 17 & 8,5 \\
\hline
\end{tabular}

mempunyai kebiasaan cebok sesudah BAK, 16 orang cebok sesudah BAB, 8 anak sering menahan kencing, 7 anak malas minum. Delapan anak sumber air MCK dari Perusahaan Daerah Air Minum (PDAM) dan 8 anak lainnya dari sumur seperti dimuat dalam Tabel 4.

Dari riwayat infeksi saluran kemih masing-masing anak pernah sakit BAK 6 orang, sakit pinggang 5 anak, rasa ingin kencing terus menerus 7 anak, kencing keruh 3 anak, demam tinggi menggigil 12 anak, mengompol 7 anak, seperti ditunjukkan dalam Tabel 5.

Jenis mikroorganisme pada 16 orang anak dengan bakteriuria asimtomatik adalah E.coli 6, Staphyloccoccus epiderminis 6, Staphylococcus aureus 2, Klebsiella 1, dan Pseudomonas aeruginosa 1 (Tabel 6).

Tabel 3. Karakteristik anak dengan bakteriuria asimtomatik berdasarkan usia dan status gizi.

\begin{tabular}{lccc}
\hline Karakteristik & \multicolumn{2}{c}{ Jenis kelamin } & Jumlah \\
\cline { 2 - 3 } & Laki-laki & Perempuan & \\
\hline Usia (tahun) & & & \\
9 & 1 & 1 & 2 \\
10 & 0 & 3 & 3 \\
11 & 0 & 7 & 7 \\
12 & 1 & 3 & 4 \\
Status gizi (BB/U) & & & \\
$\quad$ Baik & 2 & 2 & 4 \\
Sedang & 0 & 11 & 11 \\
Kurang & 0 & 1 & 1 \\
\hline
\end{tabular}

Tabel 2. Hubungan hasil biakan dengan jenis kelamin

\begin{tabular}{|c|c|c|c|c|c|}
\hline \multirow[t]{2}{*}{ Hasil Biakan } & \multicolumn{2}{|c|}{ Jenis kelamin } & \multirow[t]{2}{*}{$\mathrm{n}$} & \multirow[t]{2}{*}{$\%$} & \multirow[t]{2}{*}{$\rho$} \\
\hline & Laki-laki & Perempuan & & & \\
\hline Bermakna & 2 & 14 & 16 & 8 & $<0,05$ \\
\hline Tidak bermakna & 51 & 95 & 146 & 73 & \\
\hline Tidak tumbuh** & 10 & 28 & 38 & 19 & \\
\hline Jumlah & 63 & 137 & 200 & 100 & \\
\hline
\end{tabular}

\section{Diskusi}

Prevalensi ISK bervariasi menurut jenis kelamin dan usia. Insiden yang sebenarnya pada anak sulit ditentukan. ${ }^{1-5,7}$ Bakteriuria asimtomatik sangat sering terjadi pada anak-anak khususnya pada anak perempuan usia sekolah. ${ }^{3}$ Pada penelitian ini dijumpai 14 anak (7\%) anak perempuan usia 9-12 tahun dengan bakteriuria asimtomatik terbanyak berusia 11 tahun (7 orang). Penelitian pada anak sekolah dasar dan sekolah lanjutan di Virginia, prevalensi bakteriuria pada anak perempuan $5 \%$, sedangkan pada anak laki-laki hanya $0,03 \% .{ }^{2}$ Uji saring yang dilakukan oleh Kunin dkk mendapatkan bakteriuria asimtomatik $1 \%$ pada anak perempuan usia 6-18 tahun. ${ }^{1} \mathrm{Uji}$ saring bakteriuria asimtomatik pada anak usia sekolah di Newcastle menunjukkan prevalensi pada anak perempuan usia 7-11 tahun adalah 2,5\%. ${ }^{10}$ Infeksi jarang terjadi pada anak laki-laki pada usia yang sama. ${ }^{5}$ Pada penelitian ini dijumpai 2 anak laki-laki (1\%)

Tabel 4. Higiene dan sanitasi anak dengan bakteriuria asimtomatik

\begin{tabular}{lcc}
\hline Higiene dan sanitasi & \multicolumn{2}{c}{ Bakteriuria asimtomatik } \\
\cline { 2 - 3 } & Ya & Tidak \\
\hline Cebok sesudah BAK & 13 & 3 \\
Cebok sesudah BAB & 16 & 0 \\
Tidak lancar BAB & 1 & 15 \\
Sering menahan kencing & 8 & 8 \\
Malas minum & 7 & 9 \\
Sumber air MCK & & \\
PDAM & 8 & 0 \\
Sumur & 8 & 0 \\
\hline
\end{tabular}

BAK: buang air kecil, BAB: buang air besar, MCK: mandi,cuci, kakus, PDAM: perusahaan daerah air minum 
Sari Pediatri, Vol. 3, No. 2, September 2001

Tabel 5. Riwayat infeksi saluran kemih pada anak dengan bakteriuria asimtomatik

\begin{tabular}{lll}
\hline \multirow{2}{*}{$\begin{array}{l}\text { Riwayat Infeksi } \\
\text { Saluran Kemih }\end{array}$} & \multicolumn{2}{c}{ Bakteriuria asimtomatik } \\
\cline { 2 - 3 } & Ya & Tidak \\
\hline Sakit buang air kecil & 6 & 10 \\
Sakit pinggang & 5 & 11 \\
$\begin{array}{l}\text { Rasa ingin kencing terus } \\
\quad \text { menerus }\end{array}$ & 7 & 9 \\
Kencing keruh & 3 & 13 \\
$\begin{array}{l}\text { Demam tinggi / menggigil } \\
\text { Mengompol }\end{array}$ & 12 & 4 \\
& 7 & 9 \\
\hline
\end{tabular}

dengan bakteriuria bermakna, masing-masing berumur 9 dan 12 tahun kedua anak tersebut tidak disirkumsisi. Beberapa penelitian menunjukkan bahwa insiden ISK lebih tinggi pada anak laki-laki yang tidak disirkumsisi. ${ }^{1,9}$ Penelitian sebelumnya menunjukkan prevalensi bakteriuria asimtomatik pada anak laki-laki usia 5-18 tahun rendah yaitu $0,2 \% .{ }^{1,3,10}$

Pada penelitian ini persentase bakteriuria asimtomatik pada anak perempuan lebih tinggi daripada yang pernah dilaporkan pada penelitian uji saring ISK pada anak. Hal ini mungkin karena higiene dan sanitasi dan kebiasaan-kebiasaan anak seperti malas minum, suka menahan kencing dan kebiasaan cebok yang tidak benar (dari belakang ke depan). Urin merupakan media yang baik untuk pertumbuhan bakteri, kebiasaankebiasaan tersebut memungkinkan kuman berkembang dalam saluran kemih. ${ }^{9,11}$

E. coli adalah kuman yang paling sering ditemukan baik pada bakteriuria simtomatik maupun asimtomatik. ${ }^{1,15}$ Pada anak adanya bakteriuria pada saluran kemih umumnya berasal dari perineum dan orifisium uretra yang menjalar secara asenden, dan paling banyak disebabkan oleh kuman E.coli yang berasal dari flora kolon. ${ }^{13,5,15}$ Pada penelitian ini dijumpai bakteriuria asimtomatik terbanyak adalah E.coli (6 spesimen) dan Staphylococcus epidermidis (6 spesimen). Tabel 5 menunjukkan bahwa anak dengan bakteriuria asimtomatik mempunyai riwayat ISK sebelumnya dan kemungkinan anak tersebut menderita infeksi berulang. Spesies bakteri E. coli lebih sering ditemukan pada infeksi pertama sedangkan infeksi oleh Staphylococcus lebih sering terjadi pada infeksi ulangan baik pada anak lakilaki maupun perempuan. Umur lebih dari 1 tahun, ISK lebih sering disebabkan oleh Staphylococcus albus,
Tabel 6. Jenis mikroorganisme pada bakteriuria asimtomatik menurut umur

\begin{tabular}{lccccc}
\hline Jenis Bakteri & \multicolumn{4}{c}{ Umur } & \multirow{2}{*}{ Jumlah } \\
\cline { 2 - 5 } & 9 & 10 & 11 & 12 & \\
\hline E.coli & 1 & 2 & 2 & 1 & 6 \\
Staphyloccoccus epiderminis & - & - & - & 2 & 2 \\
Staphylococcus aureus & 1 & 2 & 3 & - & 6 \\
Pseudomonas aeruginosa & - & - & - & 1 & 1 \\
Klebsiella & - & - & 1 & - & 1 \\
\hline Jumlah & 2 & 3 & 7 & 4 & 16 \\
\hline
\end{tabular}

Staphylococcus saprophyticus, dan Proteus spesies dibandingkan E.coli. ${ }^{1-3}$ Hal ini disebabkan oleh deteksi, pencegahan dan pengobatan infeksi berulang sulit dilaksanakan, karena umumnya infeksi ulangan tidak disertai dengan demam sehingga orang tua jarang membawa anaknya untuk pemeriksaan lanjutan. ${ }^{15}$

Keterbatasan penelitian ini adalah besar sampel kurang mencukupi dan biakan dilakukan hanya satu kali, sedangkan biakan pada penderita asimtomatik sebaiknya diulang. ${ }^{9} 15$ Maka kami menyarankan untuk dilakukan penelitian lebih lanjut dengan jumlah sampel yang lebih besar.

\section{Kesimpulan}

Bakteriuria bermakna dapat dijumpai pada anak sekolah dasar yang sehat tanpa ada gejala klinis infeksi ginjal dan saluran kemih. Dijumpai perbedaaan bakteriuria asimtomatik pada anak sekolah dasar lakilaki dan perempuan usia 9-12 tahun. Prevalensi bakteriuria asimtomatik pada anak laki-laki $1 \%$ dan pada anak perempuan 7\%, dengan jenis bakteriuria terbanyak E. coli dan Staphylococcus epidermidis. Perlu ditingkatkan kewaspadaan terhadap ISK dan deteksi dini ISK melalui penyaringan bakteriuria asimtomatik pada anak sekolah dasar untuk mencegah parut ginjal dan refluks nefropati yang menyebabkan gagal ginjal sebagai komplikasi akhir ISK.

\section{Daftar Pustaka}

1. Kehr KK, Leicheter HE. Urinary tract infection. Dalam: Clinical pediatric nephrology. New York: McGraw Hill, 
1992. h. 277-306.

2. Tambunan T. Infeksi saluran kemih kronik. Disampaikan pada Kongres Nasional Ilmu Kesehatan Anak X, Bukut Tinggi, 16-20 Juni 1996.

3. Rusdidjas, Ramayati R. Infeksi saluran kemih (ISK). Dalam: Alatas H, Tambunan T, Trihono PP, penyunting. Nefrologi Anak jilid 1. Jakarta: Balai Penerbit FK UI, 1996. h. 109-31.

4. Pead L, Maskell R. Study of urinary tract infection in children in one health district. Br Med J, 1994; 309: 631-4.

5. Jandresic L, Cortwrifht K, Cowie N, Witcombe B, Stevens D. Investigation of urinary tract infection in chilhood. Br Med J: 1993; 307: 761-4.

6. Gauthier B, Edelman CM, Barnett HL, penyunting. Urinary tract infection. Dalam: Nephrology and urology for the pediatrician. Edisi ke-1. Boston: Little, Brown and Company, 1982. h. 73-85.

7. Jakobsson B, Esbjornes E, Hansson S. Minimum incidence diagnostic rate of first urinary tract infection. Pediatric 1999; 104:222-6.

8. Gorelick MH, Shaw KN. Screening test for urinary tract infection in children : A meta analysis pediatric 1999; http://www.pediatric.org/cgi/content/full/104/5/e54.

9. Jodal U. Urinary tract infection: significance, pathogenesis, clinical features and diagnosis. Dalam: Posleth waite RJ, penyunting. Clinical pediatric nephrology. Edisi ke-2.
Oxford: Betterworth-Heinemann, 1994. h. 151-9.

10. Asymptomatic bacteriuria in school children in Newcastle upon tyne. Arch Dis Child 1975: http:// www.bmj.org./cg5/content/full/309/6955/631 e ABCAbstract: 50(2): 90 .

11. Eldes JS. Urology disorders in infants and children. Dalam: Behrman RE, Kleigman RM, Arvin AM, penyunting. Nelson textbook of pediatrics. Edisi ke-16. Philadelphia: Saiders, 200. h. 1621-5.

12. Madiyono B, Moeslichan S, Sastroasmoro S, Budiman I, Purwanto SH. Perhitungan besar sampel Dalam: Sastroasmoro S, Ismael S, penyunting. Dasar-dasar metodologi penelitian klinis. Jakarta: Binarupa Aksara, 1995. h. 187-212.

13. U.S. department of health, education, and welfare. Urine collection and culture. Dalam: Laboratorium methods in clinical bacteriology course no.8380-C techniques. Atlanta: Public health service center for diseases control, 1977. h. 110-4.

14. Kass EH. Asymptomatic infections of the urinary tract. Boston: Trans assoc amer physicians, 1956. h. 56-64.

15. Alatas $H$. Penatalaksanaan infeksi saluran kemih kompleks pada anak> Dalam: Wila Wirya IGN, Alatas H, Tambunan T, Trihono PP, penyunting. Penanggulangan masalah uronefrologi pada anak. Naskah lengkap Pendidikan Kedokteran Berkelanjutan Ilmu Kesehatan Anak FKUI XXIX.; Jakarta: Balai Penerbit FK UI, 1993. h. 107-26. 